\title{
Study of the Distribution of Heavy Metals in the Atmosphere of the Guanajuato City: Use of Saxicolous Lichen Species as Bioindicators
}

\section{Estudio de la distribución de metales pesados en la atmosfera de la ciudad de Guanajuato: uso de especies de líquenes saxícolas como bioindicadores}

Puy-Alquiza María Jesús

Universidad de Guanajuato, México

Departamento de Minas, Metalurgia y Geología

E-mail: yosune.puy155@gmail.com

Miranda-Aviles Raúl

Universidad de Guanajuato, México

Departamento de Minas, Metalurgia y Geología

E-mail: rmiranda@ugto.mx

Zanor Gabriela Ana

Universidad de Guanajuato, México

División de Ciencias de la Vida (DICIVA)

E-mail: gzanor@ugto.com

Salazar-Hernández Ma. Mercedes

Universidad de Guanajuato, México

Departamento de Minas, Metalurgia y Geología

E-mail:merce@ugto.mx

Ordaz-Zubia Velia Yolanda

Universidad de Guanajuato, México

División de Arquitectura, arte y diseño

Departamento de Arquitectura

E-mail:veliaordaz@gmail.com

\begin{abstract}
The atmospheric deposition of some heavy metals was investigated using saxicolous lichen species (Xanthoparmelia mexicana (Gyeln.) Hale, Xanthoparmelia tasmanica (Hook. f. \& Taylor) Hale, Caloplaca aff. brouardii (B.deLesd.) Zahlbr, Caloplaca aff. ludificans Arup, and Aspicilia sp), samples were collected from three zones (rural, suburban and urban) along the Guanajuato city, during the months of October-November 2012, April, July, and October 2013 and January 2014. Lichen samples were analyzed using the Inductively Coupled Plasma Mass Spectrometry technique. The concentrations of heavy metals in lichen samples from the Xanthoparmelia species ranged from $\left(96.21 \mathrm{\mu g} \mathrm{g}^{-1}\right)$ for lead $(\mathrm{Pb}),\left(95.10 \mu \mathrm{g} \mathrm{g}^{-1}\right)$ for zinc $(\mathrm{Zn}),\left(58.40 \mu \mathrm{g} \mathrm{g}^{-1}\right)$ for vanadium (V), $\left(105.15 \mu \mathrm{g} \mathrm{g}^{-1}\right)$ for Chrome (Cr), and $(48.93 \mu \mathrm{g} \mathrm{g}-1)$ for Niquel (Ni). Caloplaca species (92.42, $\left.\mathrm{ug} \mathrm{g}^{-1}\right)$ for lead $(\mathrm{Pb}),\left(172.97 \mu \mathrm{g} \mathrm{g}^{-1}\right)$ for Zinc $(\mathrm{Zn}),\left(53.51 \mu \mathrm{g} \mathrm{g}^{-1}\right)$ for vanadium (V), $\left(91.23 \mu \mathrm{g} \mathrm{g}^{-1}\right)$ for copper $(\mathrm{Cu})$, respectively, and Aspicilia sp $\left(612.91 \mu \mathrm{g} \mathrm{g}^{-1}\right)$ for lead $(\mathrm{Pb}),\left(72.24 \mu \mathrm{g} \mathrm{g}^{-1}\right)$ for zinc (Zn), $\left(56.25 \mathrm{\mu g} \mathrm{g}^{-1}\right)$ for vanadium $(\mathrm{V}),\left(18.24 \mu \mathrm{g} \mathrm{g}^{-1}\right)$ for copper $(\mathrm{Cu})$. The statistical significance of between $\mathrm{Co}-\mathrm{V}, \mathrm{Ni}$ $\mathrm{Cr}$, Ni-Co, Sn-Zn, Co-Cr, Zn-Th, Sn-Th and Co-Zn concentrations confirmed anthropogenic sources mainly due to emissions from vehicular traffic, fossil fuel combustion correlations, solid waste disposal and other local anthropo-
\end{abstract}


genic activities. Pollution indices were additionally calculated by heavy metals concentrations in order to use lichens in Guanajuato city as bioindicators of air pollution. The concentration of these metals was observed to be in higher range as maximum values of $\mathrm{Pb}, \mathrm{Zn}, \mathrm{V}$, and $\mathrm{Cu}$ reported from the lichen samples for the suburban and urban zones in Guanajuato city. The accumulations of $\mathrm{Ni}$ and $\mathrm{Cr}$ from both zones are similar in concentration. The contamination factors or the pollution index factor and the pollution load index criteria revealed high levels of $\mathrm{Be}, \mathrm{Cu}, \mathrm{Co}, \mathrm{Zn}, \mathrm{Pb}$, and Th in Caloplaca species and Aspicilia sp., while Xanthoparmelia species show higher values only in $\mathrm{Be}, \mathrm{Sb}$ and $\mathrm{Pb}$. The results revealed that the most sensitive lichens were Aspicilia sp., with the highest levels of $\mathrm{Pb}$. The results obtained reveal important contributions towards understanding of heavy metal deposition patterns and provide baseline data that can be used for potential identification of areas at risk from atmospheric heavy metals contamination in the region. The use of saxicolous lichens provide a cost-effective approach for monitoring regional atmospheric heavy metal contamination and may be effectively used in large scale air pollution monitoring programmer.

Keywords: lichens, heavy metal pollution, indicator, Guanajuato city.

\section{Resumen}

En este estudio se analizaron la concentraciones de algunos metales pesados encontrados en la atmosfera de la ciudad de Guanajuato, empleando para ello, especies de líquenes saxícolas (Xanthoparmelia mexicana (Gyeln.) Hale, Xanthoparmelia tasmanica (Hook.f. E Taylor) Hale, Caloplaca aff. brouardii (B.deLesd.) Zahlbr, Caloplaca aff. ludificans Arup, and Aspicilia sp) recolectados en tres zonas (rural, suburbana y urbana) a lo largo de los meses octubre-noviembre de 2012, abril, julio y octubre de 2013, así como enero de 2014. Las muestras de líquenes se analizaron usando la técnica de espectrometría de masas de plasma acoplado inductivamente. La concentración de metales pesados en las muestras de los líquenes de la especie de Xanthoparmelia van de $\left(96.21 \mu \mathrm{g} \mathrm{g}^{-1}\right)$ para plomo $(\mathrm{Pb}),\left(95.10 \mu \mathrm{g} \mathrm{g}^{-1}\right)$ para zinc $(\mathrm{Zn}),\left(58.40 \mu \mathrm{g} \mathrm{g}^{-1}\right)$ para vanadio $(\mathrm{V}),\left(105.15 \mu \mathrm{g} \mathrm{g}^{-1}\right)$ para Cromo (Cr) y $\left(48.93 \mu \mathrm{g} \mathrm{g}^{-1}\right.$ ) para Niquel (Ni). Caloplaca especie (92.42, $\left.\mu \mathrm{g} \mathrm{g}^{-1}\right)$ para plomo (Pb), (172.97 $\left.\mu \mathrm{g} \mathrm{g}^{-1}\right)$ para Zinc ( $\left.\mathrm{Zn}\right),(53.51$ $\left.\mu \mathrm{g} \mathrm{g}^{-1}\right)$ para vanadio $(\mathrm{V}),\left(91.23 \mu \mathrm{g} \mathrm{g}^{-1}\right)$ para cobre $(\mathrm{Cu})$, respectivamente, y Aspicilia sp $\left(612.91 \mu \mathrm{g} \mathrm{g}^{-1}\right)$ para plomo $(\mathrm{Pb}),(72.24$ $\left.\mu \mathrm{g} \mathrm{g}^{-1}\right)$ para zinc $(\mathrm{Zn}),\left(56.25 \mu \mathrm{g} \mathrm{g}^{-1}\right)$ para vanadio $(\mathrm{V}),\left(18.24 \mu \mathrm{g} \mathrm{g}^{-1}\right)$ para cobre $(\mathrm{Cu})$. La estadística entre las concentraciones de Co-V, Ni-Cr, Ni-Co, Sn-Zn, Co-Cr, Zn-Th, Sn-Th and Co-Zn confirma una fuente antropogénica, principalmente debida a las emisiones del tráfico vehicular, combustión y actividades antropogénicas locales. Los indices de contaminación se calcularon, con la finalidad de utilizar los líquenes estudiados como indicadores de calidad del aire en la ciudad de Guanajuato. Se observaron valores altos en $\mathrm{Pb}, \mathrm{Zn}, \mathrm{V}$ y $\mathrm{Cu}$. La concentración de $\mathrm{Ni}$ y $\mathrm{Cr}$ en ambas zonas son similares. Los factores de contaminación o el factor de indice de la contaminación y los criterios de indice de contaminación, revelaron niveles elevados de $\mathrm{Be}, \mathrm{Cu}, \mathrm{Co}, \mathrm{Zn}, \mathrm{Pb}$ y Th en las especies Caloplaca y Aspicilia sp., mientras que las especies Xanthoparmelia muestran los valores más altos solo en $\mathrm{Be}, \mathrm{Sb}$ y $\mathrm{Pb}$. Los resultados revelaron que el liquen más sensible fue la Aspicilia sp, con los niveles más altos de Pb. Los resultados obtenidos revelan importantes contribuciones para la comprensión de los patrones de deposición de metales pesados y proporcionan a su vez datos de referencia que pueden utilizarse para su posible identificación de zonas de riesgo. El uso de líquenes saxícolas ofrece un enfoque rentable para el monitoreo de la contaminación por metales pesados en la atmosfera y pueden utilizarse con eficacia en la vigilancia de la calidad del aire.

Descriptores: líquenes, contaminación metales pesados, indicador, Ciudad de Guanajuato.

\section{INTRODUCTION}

In the last decades, several studies have shown that lichens are excellent bioindicators of air pollution (Addison and Puckett, 1980; Farner et al., 1992; Gries, 1996; Jeran et al., 2002; Nash and Gries, 2002; Gartner Lee et al., 2006; Kinalioglu et al., 2010), mainly due to their susceptibility to the deposition of airborne pollutants in the form of soluble salts and particles (Nimis et al., 2002). Lichens accumulate and retain macronutrients, trace elements and metal elements to concentrations that exceed their physiological requirements, tolerating high concen- trations of toxic pollutants. The accumulation of elements in lichens occurs by particulate trapping, active uptake of anions, passive absorption of cations and ion exchange Nieboer et al. (1978). According to Boonpragob et al. (1989) and Garty (2001), the residence of elements in lichens is different for macronutrients, trace elements and metals. The macronutrients are mobile and their concentrations in lichens can change seasonally, whereas trace elements and metals are less mobile and accumulate in lichen species over time with the advantage of metal contents decreasing when air quality improves. Information about atmospheric pollutant levels in industrial and 
mining areas is particularly scarce in Mexico and the use of lichens as bioindicators of atmospheric pollution has received little attention. Mining activities are widely known as the main pollutant source by releasing high concentrations of heavy metals to the environment (Conesa et al., 2007). Specifically, mining activities in the Guanajuato city have been developed for over 500 years, constituting the most important economic activity in the region. For the last five centuries, mineral deposits have been utilized to obtain commercial quantities of iron, lead, zinc, copper, gold and silver. Iron is present in oxides (hematite, and magnetite) and sulfides (pyrite); lead and zinc occur in galena and sphalerite, while copper is present in chalcopyrite (Puy et al., 2013). No literature on heavy metal pollution in the Guanajuato city is available and neither on the use of lichens as bioindicators for atmospheric trace elements and heavy metal deposition. The objective of this work was the use of saxicolous lichens as bioindicators of atmospheric deposition of trace elements and heavy metals in the city of Guanajuato. Samples were collected at three sites: rural, suburban and urban; the first is considered a pristine area located in the forest known as 'La Bufa' and the remaining two are influenced by anthropogenic activities (Figure 1). Pollution indices, such as contamination factors ( $\mathrm{CFs}$ ) and pollution load index (PLI) were used to determine the pollution state and to assess the possible sources of contaminants. This study can be considered as a basis for future research on air quality monitoring in areas influenced by strong human impact (mining extractions, industry and vehicular emissions).

\section{Materials AND MEthods}

\section{StUdY AREA}

Guanajuato is a city in central Mexico and the capital of the state bearing the same name. The origin and the economic development of the city come from the discovery of mines in the surrounding mountains. The city is located at 2,000 meters above sea level and is characterized by a regional semi-arid climate. Temperature varies from 6 to $20^{\circ} \mathrm{C}$ in winter and 21 to $32^{\circ} \mathrm{C}$ in summer. Most of the rainfall occurs between May and September, with a total annual rainfall reaching $700 \mathrm{~mm}$ /year. The trees, which generally reach heights of $15 \mathrm{~m}$, are distributed mostly at the summit of the hills where mining has not yet spread. The site was selected due to the anthropogenic activities such as mining, stone crushers, and intense vehicular flow. Lichen specimens were collected in three zones in Guanajuato city:

1. Urban (four sites were sampled: Plaza de Los Angeles (14Q265491-2325649), Belen (14Q2653882325963), Teatro Principal (14Q265949-2325548) and Universidad de Guanajuato (14Q265748-2325687).

2. Suburban (two sites were sampled: Pastita (14Q266352-2324963), and Music School (14Q 267277-2324000), and

3. Rural (one site were sampled: la Bufa-14Q 2665652323525), (Figure 1).

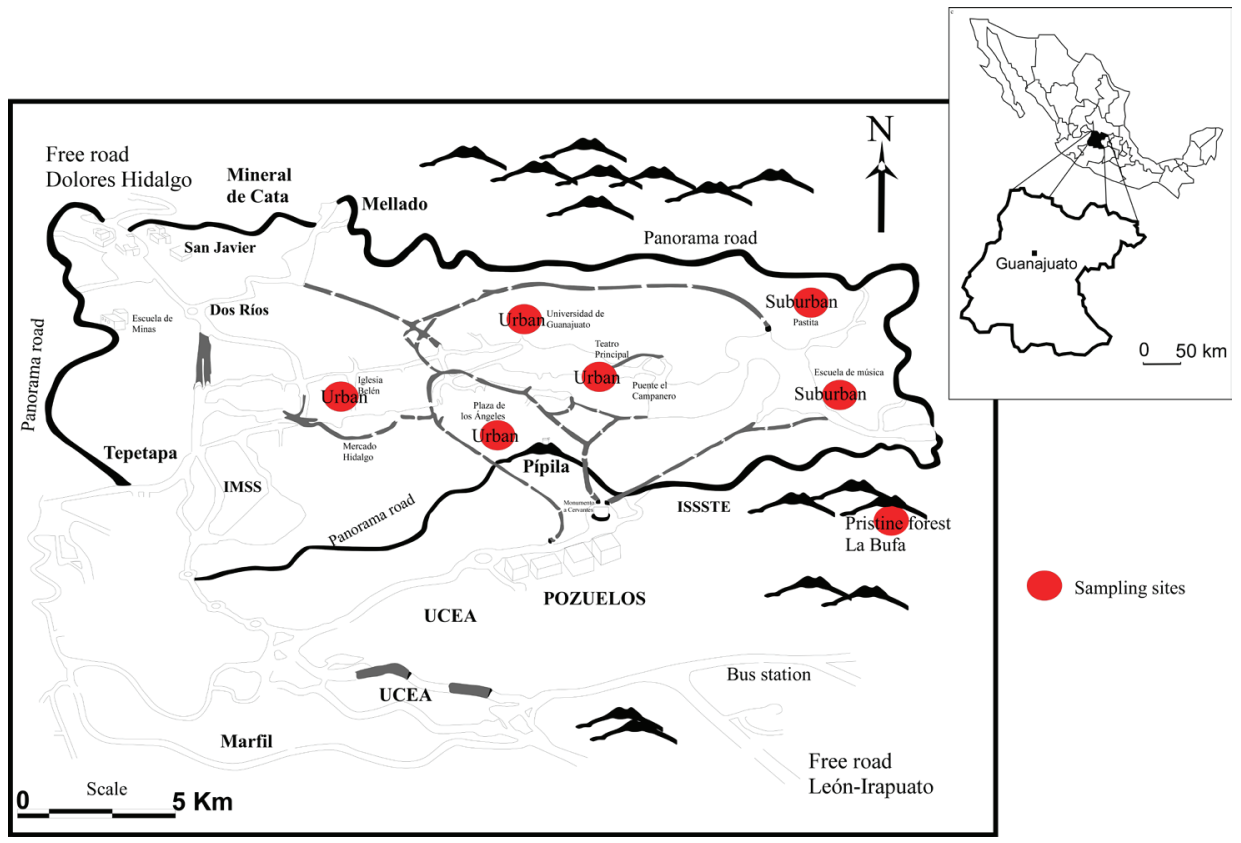

Figure 1. General map of Guanajuato city, showing the locations of the studied sites 


\section{SAMPLING AND SAMPLE TREATMENT}

Lichen specimens were sampled at the same time during October and November 2012, April, July, and October 2013 and January 2014 in three zones (Figure 1): rural (pristine forest 'La Bufa'), suburban (influenced by mining and stone crushers), and urban (influenced by mining and intense vehicular flow). Collections of the lichens, together with their substrates, were carefully sampled directly from uncontaminated rocks in the rural zone (named here standard reference material or SRM) and the other samples were taken from rocks influenced by human activities in suburban and urban zones (termed here as influenced by human activities or IHA). A minimum of three samples for each species were collected in selected sites with a steel knife and approximately 3-4 $\mathrm{g}$ of the lichen thallus were taken for each species. The specimens were stored in perforated plastic bags, maintained at $4^{\circ} \mathrm{C}$ during the transport to the laboratory and refrigerated at $-4^{\circ} \mathrm{C}$ before use for the analysis of ICP-MS. The lichen specimens were reviewed taxonomically using specialized keys (Nash et al., 2004, 2007), taking into account their vegetative and reproductive characteristics (observed in the Olympus BX41 optical microscope); and chemical (lichen acids present), based on the reactions of the reagents: potassium hydroxide $10 \%(\mathrm{~K})$ and saturated calcium hypochlorite solution (C), as well as combinations of both (KC).

\section{GeOloGy}

The studied lichen grew in sandstones of the Losero Formation located in the pristine forest of 'La Bufa' (Figure 2). The sandstone Losero Formation shows great diversity in grain sizes, from coarse to fine sand. The grains generally are subrounded to angular and show a poor selection with respect to grain size. In regards to composition, these sandstones are immature, with high contents of rock fragments in size ranging from some micrometers up to several millimeters. Optical microscopy analyses show that all the lithofacies contain quartz, feldspars, biotite, volcanic lithics, metamorphic lithics and iron oxides in small quantities (Figure 3).

\section{GeOChemical anAlysis of the SANDStOnes Of the LOSERO FORMATION}

The stone material used for the geochemical analyses is crushed to a size smaller than $75 \mathrm{u}$ (200 mesh), and the concentration of major elements and trace elements from the powdered samples were determined using mass spectrometry-Inductively Coupled Plasma (ICPMS) (Table 1).
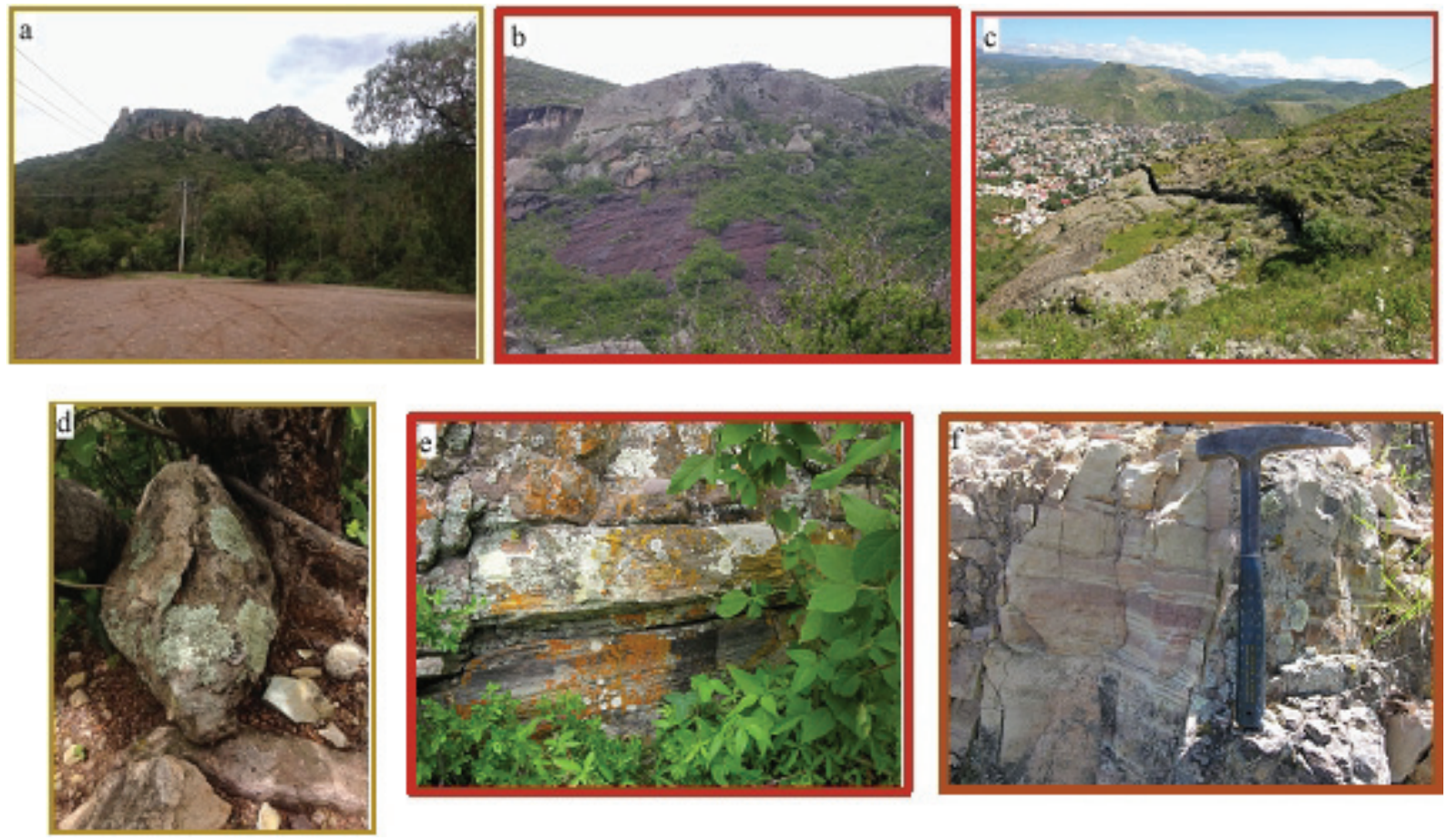

Figure 2. a, b, c) Forest La Bufa; d, e) lichen species in Losero Formation; f) Sandstone of Losero Formation 


\begin{tabular}{|lr|}
\hline $\begin{array}{l}\text { sandstone } \\
\text { Composition }\end{array}$ & $\%$ \\
\hline Quartz & 32 \\
Plagioclase & 25 \\
Biotite & 7 \\
$\begin{array}{l}\text { Rock fragments } \\
\text { volcanic }\end{array}$ & 13 \\
$\begin{array}{l}\text { Rock fragments } \\
\text { metamorphic }\end{array}$ & 19 \\
Iron Oxides & 4 \\
Total & 100 \\
\hline
\end{tabular}
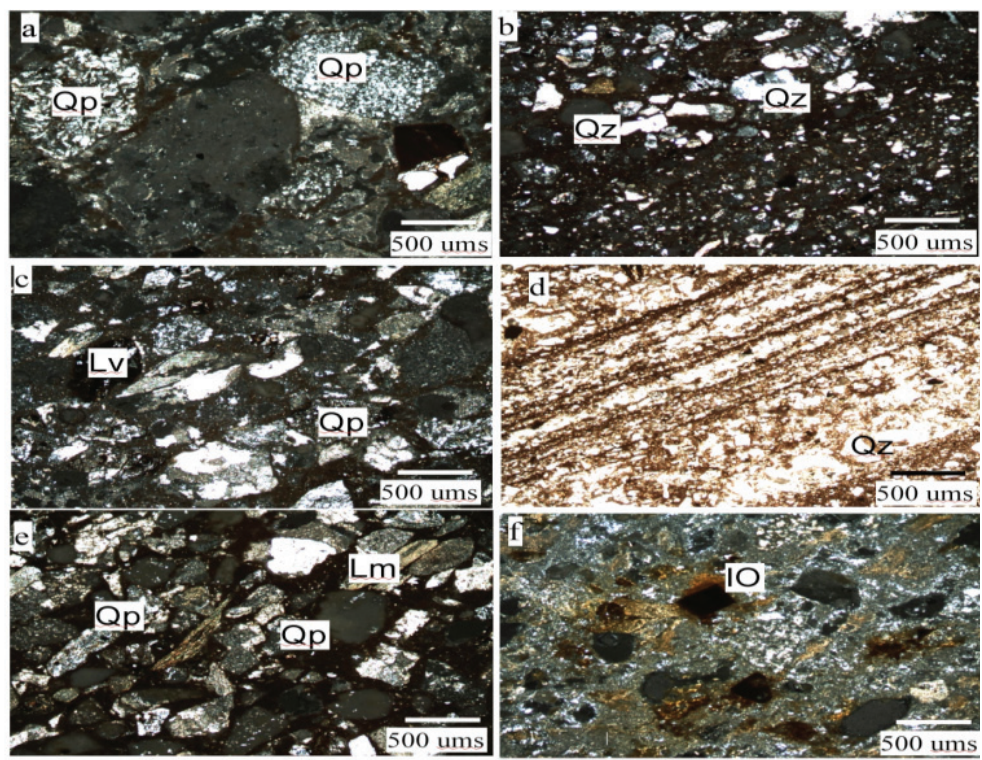

Figure 3. Mineralogical composition of sandstones of the Losero Formation, a) photomicrograph showing quartz grains consisting mainly of polycrystalline quartz grains, b) quartz grains consisting mainly of monocrystalline grains, c) volcanic fragments, d) monocrystalline quartz grains and plane parallel laminae, e) contact grains, f) iron oxides

Table 1. Geochemical analysis of the sandstones of the Losero Formation collected from rural (pristine forest "La Bufa") in the Guanajuato city. ----no detected

\begin{tabular}{cc}
\hline $\begin{array}{c}\text { The major } \\
\text { and trace elements }\end{array}$ & $\begin{array}{c}\text { Sandstone of the } \\
\text { Losero Formation }\end{array}$ \\
\hline $\mathrm{Na}_{2} \mathrm{O}(\%)$ & --- \\
$\mathrm{Al}_{2} \mathrm{O}(\%)$ & 17.31 \\
$\mathrm{SiO}_{2}(\%)$ & 80.95 \\
$\mathrm{~K}_{2} \mathrm{O}(\%)$ & 8.45 \\
$\mathrm{MgO}(\%)$ & --- \\
$\mathrm{CaO}(\%)$ & 0.6 \\
$\mathrm{Fe}_{2} \mathrm{O}_{3}(\%)$ & 0.43 \\
$\mathrm{Be}(\mu g g-1)$ & 3.41 \\
$\mathrm{Ni}(\mu g g-1)$ & 7.39 \\
$\mathrm{Cu}(\mu g g-1)$ & 9.12 \\
$\mathrm{Co}(\mu g g-1)$ & 2.80 \\
$\mathrm{Sn}(\mu g g-1)$ & 5.70 \\
$\mathrm{Sb}(\mu g g-1)$ & 1.19 \\
$\mathrm{Zn}(\mu g g-1)$ & 37.88 \\
$\mathrm{~Pb}(\mu g g-1)$ & 6.14 \\
$\mathrm{Cr}(\mu g g-1)$ & 17.71 \\
$\mathrm{~V}(\mu g g-1)$ & 43.55 \\
$\mathrm{Th}(\mu g g-1)$ & 0.23 \\
\hline
\end{tabular}

Inductinely Coupled Plasma Mass Spectrometry (ICP-MS)

Analyses of trace elements and heavy metals were performed by ICP-MS using a Thermo Series XII instrument at 'Centro de Geociencias-UNAM' (Querétaro, México). Lichen samples were previously crushed to a size of $75 \mu$. For sample preparation was used the methodology of Mori et al. (2009).

\section{StATISTICAL ANALYSIS}

A one-way analysis of mean concentrations, standard deviations, median, minimum, maximum, correlation and cluster analysis were carried out using the NCSS2007 software.

\section{Pollution INDICES}

The air pollution status of the studied area was quantified using the CFs by Nyarko et al. (2004) and (PLI) Tomlinson et al. (1980), to assess the metal contents in the lichens. The CFs and PLI were computed using Microsoft Excel 2007.

\section{CFS}

The CFs is the ratio obtained by dividing the average concentration of elements in the samples and the average concentration of elements in the standard or an unpolluted area (i.e. $\mathrm{CFs}=\mathrm{Cs} / \mathrm{Cc}$; where $\mathrm{Cs}=$ average concentration of element in the sample, $\mathrm{C}_{\mathrm{C}}=$ average concentration of element in the standard). According to Bhuiyan et al. (2010) and Harikumar et al. (2010), the contamination levels may be classified based on their grades and intensities (<1.2: grade I, Intensity unpolluted area; $1.2-2$ grade II, Intensity Lightly polluted area; 2-3grade III, Intensity Medium polluted area; > 3grade IV, Intensity Heavily polluted area). 
PLI

Tomlinson et al. (1980) proposed the use of PLI as an empirical index which provides a simple method for assessing the levels of heavy metal pollution: $\mathrm{PLI}=(\mathrm{CF} 1$ x CF2 x CF3x.... CFn) ${ }^{1 / n}$ (where $\mathrm{CF}=$ Contamination Factor, $n=$ number of metals). PLI values $>1$ correspond to polluted stages and values $<1$ indicate unpolluted stages (Harikumar et al., 2009), whereas values equaling to $1 \mathrm{imply}$ that only baseline levels of pollutants are present (Tomlinson et al., 1980).

\section{Results AND Discussion}

\section{RECOGNITION OF LICHEN SPECIES}

The lichen specimens were reviewed taxonomically using specialized keys (Nash et al., 2004, 2007), taking into account their vegetative and reproductive characteristics (observed with an Olympus BX41 optical microscope); as well as chemical (lichen acids present), based on the reactions of the reagents: potassium hydroxide $10 \%(\mathrm{~K})$ and saturated calcium hypochlorite solution (C). Microscopic observations and chemical tests allowed the identification of five species of saxicolous lichens, two of them foliose: Xanthoparmelia mexicana (Gyeln.) Hale, and Xanthoparmelia tasmanica (Hook. f. $\mathcal{E}$ Taylor) Hale, and three crustose: Caloplaca aff. brouardii (B.deLesd.) Zahlbr, Caloplaca aff. ludificans Arup, and Aspicilia sp (Figure 4). Xanthoparmelia mexicana (Gyeln) Hale, which belongs to the family Parmeliaceae, presents a rosette-like foliose thallus and its photobiont is a green algae; the upper surface of the thallus has a yellowish green color, without imbricated lobes, $4 \mathrm{~mm}$ wide, the bone is white and the underside has a pale brown color moderate to densely rizinada, the rizinas are pale brown; slightly adhered to the substrate. The specimen, with no apothecia or pycnidia, has isidia (asexual reproductive structures) plentifully subglobose. Reactions are presenting $\mathrm{K}, \mathrm{C}, \mathrm{KC}$ on the upper surface and spinal $\mathrm{K}+$ yellow to dark red shifting and C, KC. Xanthoparmelia tasmanica (Hook $f$ \& Taylor) Hale, belongs to the family Parmeliaceae, presents a foliose thallus grows as a rosette and its photobiont a green algae; the upper surface of the thallus is yellowish green, with small lobes $2-3 \mathrm{~mm}$ wide, and overlapping. Bone is white and the lower surface is black with little rizinas in black; slightly adhered to the substrate. Shows apothecia with brown disc 2 to $25 \mathrm{~mm}$; presents pycnidia (asexual reproductive structures). Reactions are presenting $\mathrm{K}, \mathrm{C}, \mathrm{KC}$, in the upper crust; while the bone is $\mathrm{K}+$ yellow changing to dark red and C-KC. Caloplaca aff. brou- ardii (.B.deLesd) Zahlbr corresponds to the Teloschistaceae family, has a crusty thallus, its photobiont a green alga; talus is areolado (forming plaques) to the center and form elongated lobes to the margins of 0.3 to $0.5 \mathrm{~mm}$ wide. The upper surface is orange, no bottom surface and is tightly bound to the substrate. Presents flat circular apothecium, with the disc and the margin of the same color of the thallus, with a diameter of 0.2 to 0.8 $\mathrm{mm}$; in the specimen, the immature apothecium was presented and it was not possible to observe spores. The central portion of the stalk shows isidia (asexual reproductive structures) as buds. The reactions are presented $C$ and $K+$ purple in the top surface and the margin of apothecium. Caloplaca aff. ludificans Arup, the Teloschistaceae family, has a crusty thallus underdeveloped, areolado (forming plates) over its entire surface without forming elongated lobes, its photobiont a green alga. The upper surface is orange-yellow; no bottom surface and is tightly bound to the substrate. Features, as well, numerous orange disc-shaped apothecia ranging from 0.4 to $0.8 \mathrm{~mm}$ in diameter, spores are polariloculares (two cores) 9-11 x 5-6 microns eight per ascus are presented. No asexual reproduction structures were observed. The reactions presented $\mathrm{C}$ and $\mathrm{K}+$ purple in the top surface and the margin of apothecium. Aspicilia sp., the Megasporace family, is a crusty lichen, (forming plaques) in the center, form rounded lobes marginally. The upper surface is gray, somewhat greenish, bone is white and its lower part is not visible. The photobiont is green algae. The analyzed sample is very small, with a diameter of $2 \mathrm{~mm}$, and immature, no structure of either sexual or asexual reproduction was observed. Reactions to $\mathrm{K}, \mathrm{C}$ and $\mathrm{KC}$, are negative.

\section{GeOChemical analysis of major AND tRACE ElEMENTS}

The major and trace elements in the sandstone of the Losero Formation and lichens in the pristine forest ' $\mathrm{La}$ Bufa', are shown in Table 2. A high concentration of $\mathrm{Si}$ $(80.95 \%)$, and $\mathrm{Al}_{2} \mathrm{O}\left(17.31 \mu \mathrm{g} \mathrm{g}^{-1}\right)$, in the sandstone of the Losero Formation can be observed. In response to lichens (Xanthoparmelia mexicana (Gyeln.) Hale, Xanthoparmelia tasmanica (Hook. f. \& Taylor) Hale, Caloplaca aff. brouardii (.B.deLesd) Zahlbr, Caloplaca aff. ludificans Arup, and Aspicilia sp.) these show high values of major and trace elements when compared with the values of sandstones. In the Xanthoparmelia species the resulting values correspond to $\mathrm{CaO}(27.9 \%), \mathrm{Fe}_{2} \mathrm{O}_{3}(13.32 \%), \mathrm{Cu}\left(21.71 \mu \mathrm{g} \mathrm{g}^{-1}\right)$, $\mathrm{Zn}\left(95.10 \mu \mathrm{g} \mathrm{g}^{-1}\right)$, and $\mathrm{Pb}\left(21.40 \mu \mathrm{g} \mathrm{g}^{-1}\right)$, respectively (Table 2). For Caloplaca species, the values are $\mathrm{CaO}(5.88 \%)$, $\mathrm{Fe}_{2} \mathrm{O}_{3}(22.35 \%), \mathrm{Cu}\left(18.09 \mu \mathrm{g} \mathrm{g}^{-1}\right), \mathrm{Zn}\left(172.97 \mu \mathrm{g} \mathrm{g}^{-1}\right)$, and $\mathrm{Pb}\left(26.42 \mu \mathrm{g} \mathrm{g}^{-1}\right)$, respectively (Table 2), while the Aspici- 

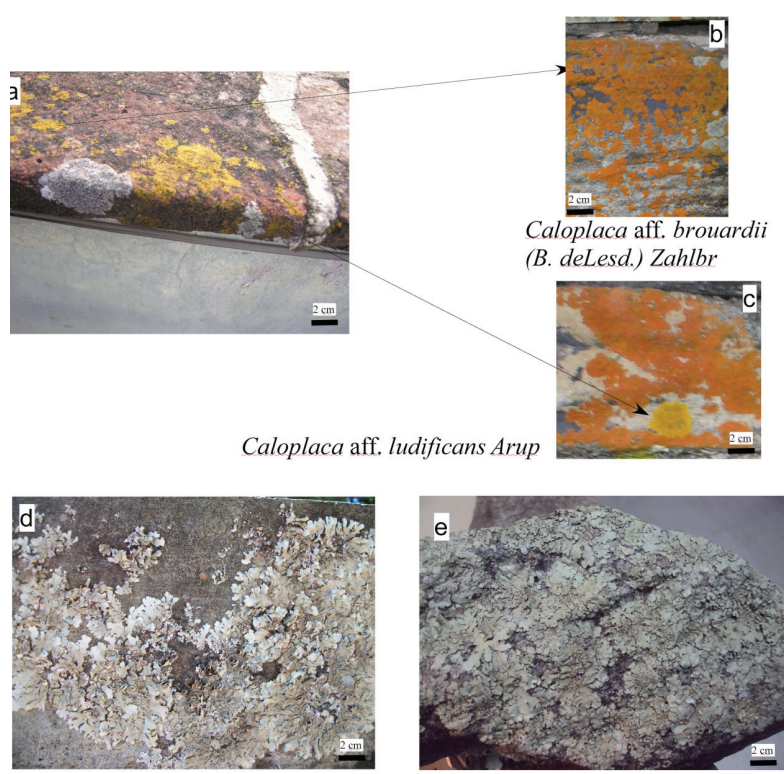

Xanthoparmelia mexicana (Gylen) Hale

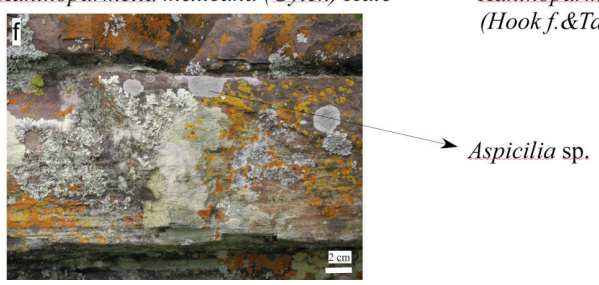

Figure 4. The lichen species, a) Caloplaca sp, b) Caloplaca aff. brouardii, c) Caloplaca aff. Ludificans, d) Xanthoparmelia mexicana, e) Xanthoparmelia tasmanica, f) Aspicilia sp

lia, sp. Shows the following values in $\mathrm{CaO}(8.2 \%), \mathrm{Fe}_{2} \mathrm{O}_{3}$

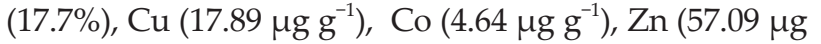
$\left.\mathrm{g}^{-1}\right)$, and $\mathrm{Pb}\left(20.06 \mu \mathrm{g} \mathrm{g}^{-1}\right)$, (Table 2).

\section{HeAVY METAL CONTENTS IN LICHEN SPECIES}

Heavy metal concentrations ( $\mathrm{Be}, \mathrm{Ni}, \mathrm{Cu}, \mathrm{Co}, \mathrm{Sn}, \mathrm{Sb}, \mathrm{Zn}$, $\mathrm{Pb}, \mathrm{Cr}, \mathrm{V}$, and $\mathrm{Th}\left(\mu \mathrm{g} \mathrm{g}^{-1}\right)$ in the nine analyzed lichens from SRM (rural zone) and IHA (suburban and urban zone) are shown in Table 3. Heavy metal concentrations from the rural, suburban and urban zone display a wide range of values. Among the analyzed metals, $\mathrm{Pb}$, $\mathrm{Zn}, \mathrm{Cr}, \mathrm{Cu}, \mathrm{V}$, and $\mathrm{Ni}$ show a higher range of variability, while $\mathrm{Be}, \mathrm{Co}, \mathrm{Sb}$ and $\mathrm{Th}$ are the least variable. The selectivity sequence of metals in the three studied areas were $\mathrm{Pb}>\mathrm{Zn}>\mathrm{Cr}>\mathrm{Cu}>\mathrm{V}>\mathrm{Ni}>\mathrm{Sn}>\mathrm{Th}>\mathrm{Co}>\mathrm{Be}>\mathrm{Sb}$. Two groups of metals could be clustered (Figure 5), according to their maximum values from the uncontaminated and contaminated zones: group 1 is formed by $\mathrm{Be}, \mathrm{Ni}, \mathrm{Co}, \mathrm{Sn}, \mathrm{Zn}$, $\mathrm{Cr}, \mathrm{V}$, and Th with the highest contents in the rural zone and group 2 includes $\mathrm{Cu}$, and $\mathrm{Pb}$ with the highest concentrations in the suburban and urban zone, and $\mathrm{Sb}$ in suburban zone. In group 1 , the selectivity sequence of elements were $\mathrm{Zn}>\mathrm{Cr}>\mathrm{V}>\mathrm{Ni}>\mathrm{Sn}>\mathrm{Pb}>\mathrm{Cu}>\mathrm{Th}>\mathrm{Co}>\mathrm{Be}>\mathrm{Sb}$, varying $\mathrm{Zn}$ from 57.09 to $172.97 \mu \mathrm{g} \mathrm{g}^{-1}$ and $\mathrm{Sb}$ from 1.31 to $1.68 \mathrm{\mu g} \mathrm{g}^{-1}$ (Table 2). Conversely, in group 2 the selectivity sequence of metals were $\mathrm{Pb}>\mathrm{Cu}>\mathrm{Zn}>\mathrm{V}>\mathrm{Sb}>\mathrm{Cr}>\mathrm{Sn}$ $>\mathrm{Th}>\mathrm{Ni}>\mathrm{Co}>\mathrm{Be}$, ranging $\mathrm{Pb}$ between $92.23-612.91 \mu \mathrm{g}$ $\mathrm{g}^{-1}$ and $\mathrm{Cu}$ between 15.73 - $91.23 \mu \mathrm{g} \mathrm{g}^{-1}$ (Table 2). According to these results, metals clustered in group 1 (Be, $\mathrm{Ni}, \mathrm{Co}, \mathrm{Sn}, \mathrm{Sb}, \mathrm{Zn}, \mathrm{Cr}, \mathrm{V}$ and Th) with the highest concentrations in the rural zone could suggest that a natural source, the rock, is controlling the geochemical signals in the lichens. Conversely, metals conforming group $2(\mathrm{Cu}$ and $\mathrm{Pb})$ undoubtedly indicate that metals deposited on lichens come from an anthropogenic source in the suburban and urban zone. Furthermore, a selective deposition of metals is observed in the lichen specimens. Xanthoparmelia species best accumulate $\mathrm{Cr}$, $\mathrm{V}, \mathrm{Ni}$ and $\mathrm{Co}$ and with the highest values in the rural zone: $105.15,58.40,48.93$ and $7.00 \mu^{-1} \mathrm{~g}^{-1}$, respectively. Caloplaca species, however, show maximum levels of $\mathrm{Zn}, \mathrm{V}, \mathrm{Sn}, \mathrm{Th}$, and $\mathrm{Sb}$ for the rural zone and $\mathrm{Cu}$ for the urban zone: 172.97, 53.51, 27.56, 13.13, 1.68 and 91.23 $\mu \mathrm{g} \mathrm{g}^{-1}$, respectively. Finally, Aspicilia sp has the highest concentration of $\mathrm{Pb}\left(612.91-600.92 \mu \mathrm{g} \mathrm{g}^{-1}\right)$ in both the suburban and urban zone, respectively. It should be noted that although all lichen samples are clearly $\mathrm{Pb}$ enriched in polluted zones (IHA: 92.23-600.92 $\mu \mathrm{g} \mathrm{g}^{-1}$ ) with respect to SRM $\left(20.06 \mu \mathrm{g} \mathrm{g}^{-1}\right)$. According to Nieboer et al. (1978), threshold values for $\mathrm{Pb}$ in lichens range from 5 to $100 \mu \mathrm{g} \mathrm{g}^{-1}$, reaching enhanced levels above 100 $\mu \mathrm{g} \mathrm{g}^{-1}$, whereas the threshold values of $\mathrm{Cu}$ for lichens are 1-50 $\mu \mathrm{g} \mathrm{g}^{-1}$. The same authors found in their study extreme values for $\mathrm{Zn}$ in lichen species reaching levels up to $500 \mu \mathrm{g} \mathrm{g}^{-1}$. $\mathrm{Pb}$ and $\mathrm{Cu}$ contents determined in the present study show that the study area is clearly polluted by $\mathrm{Pb}$, and $\mathrm{Cu}$. These results reveal that high concentrations of $\mathrm{Pb}$ and $\mathrm{Cu}$ accumulated by lichens in the suburban and urban zone may be explained by the heavy traffic flow, as well as industrial and mining emissions in the most populated area of Guanajuato. In the case of $\mathrm{Zn}$, it accumulated with a maximum value of $172.97 \mu \mathrm{g} \mathrm{g}^{-1}$ in the pristine area (Caloplaca species), exceeding widely the common levels documented in lichens for this metal. In particular, enriched contents of Zn in Xanthoparmelia and Caloplaca communities may be contributed by natural sources and amplified by metabolic interactions in the lichens. Brunialti and Frati (2007) have recorded that $\mathrm{Cu}$ and $\mathrm{Zn}$ are essential elements for lichen metabolisms. Zn contents in Caloplaca species are lower in anthropogenic areas (IHA, maximum value: $\left.77.11 \mu \mathrm{g} \mathrm{g}^{-1}\right)$ in comparison with the rural zone $\left(172.97 \mu \mathrm{g} \mathrm{g}^{-1}\right)$. 
DOI: http://dx.doi.org/10.22201/fi.25940732e.2017.18n1.010

Study of the Distribution of Heavy Metals in the Atmosphere of the Guanajuato City: Use of Saxicolous lichen Species as Bioindicators

Table 2. Chemical compositions of lichen and sandstone samples collected from rural (pristine forest "La Bufa") in the Guanajuato city. --- no detected

\begin{tabular}{|c|c|c|c|c|c|}
\hline $\begin{array}{c}\text { The major and trace } \\
\text { elements }\end{array}$ & $\begin{array}{l}\text { Sandstone of the Losero } \\
\text { Formation }\end{array}$ & $\begin{array}{l}\text { Xanthoparmelia species } \\
\text { lichen }\end{array}$ & $\begin{array}{c}\text { Caloplaca species } \\
\text { lichen }\end{array}$ & Aspicilia sp & Mean lichen \\
\hline $\mathrm{Na}_{2} \mathrm{O}(\%)$ & --- & --- & --- & --- & --- \\
\hline $\mathrm{Al}_{2} \mathrm{O}(\%)$ & 17.31 & 12.82 & 11.13 & 15.13 & 13.0266 \\
\hline $\mathrm{SiO}_{2}(\%)$ & 80.95 & 32.42 & 54.28 & 38.13 & 41.61 \\
\hline $\mathrm{K}_{2} \mathrm{O}(\%)$ & 8.45 & 13.52 & 5.68 & 5.03 & 8.07666 \\
\hline $\mathrm{MgO}(\%)$ & --- & --- & 1.85 & 1.9 & 1.25 \\
\hline $\mathrm{CaO}(\%)$ & 0.6 & 27.9 & 5.88 & 8.2 & 13.9933 \\
\hline $\mathrm{Fe}_{2} \mathrm{O}_{3}(\%)$ & 0.43 & 13.32 & 22.35 & 17.7 & 17.79 \\
\hline $\mathrm{Be}(\mu g g-1)$ & 3.41 & 3.1021 & 3.1064 & 14.8402 & 7.0162 \\
\hline $\mathrm{Ni}(\mu g g-1)$ & 7.39 & 48.9306 & 6.4322 & 14.0175 & 23.1267 \\
\hline $\mathrm{Cu}(\mu g g-1)$ & 9.12 & 21.7104 & 18.0997 & 17.8997 & 19.2366 \\
\hline $\operatorname{Co}(\mu g g-1)$ & 2.80 & 7.0012 & 3.9307 & 4.641 & 5.1909 \\
\hline $\operatorname{Sn}(\mu g g-1)$ & 5.70 & 5.7003 & 27.5609 & 6.224 & 13.1617 \\
\hline $\mathrm{Sb}(\mu g g-1)$ & 1.19 & 1.4497 & 1.6869 & 1.3181 & 1.4849 \\
\hline $\mathrm{Zn}(\mu g g-1)$ & 37.88 & 95.1035 & 172.971 & 57.0977 & 108.3907 \\
\hline $\mathrm{Pb}(\mu g g-1)$ & 6.14 & 21.4031 & 26.4245 & 20.0676 & 22.6317 \\
\hline $\operatorname{Cr}(\mu g g-1)$ & 17.71 & 105.1565 & 29.3347 & 15.1433 & 49.8781 \\
\hline $\mathrm{V}(\mu g g-1)$ & 43.55 & 58.4043 & 53.5166 & 56.2548 & 56.0585 \\
\hline $\operatorname{Th}(\mu g g-1)$ & 0.23 & 5.1625 & 13.1387 & 5.1917 & 7.8309 \\
\hline
\end{tabular}

\section{Statistical ANAlYsis}

\section{MeAn, STANDARD DEVIATION AND CORRELATION}

The statistical analyses performed in heavy metal accumulations on lichens are presented in Table 4. Mean, standard deviation, Min, Max, Med for each of the eleven metals analyzed in lichen thallus from rural, suburban and urban zones resulted significant at $<0.05$. According to statistical tests, the selectivity sequence of metals resulted as follows: Suburban (zone 1):

mean

$\mathrm{Pb}>\mathrm{Zn}>\mathrm{Cu}>\mathrm{V}>\mathrm{Cr}>\mathrm{Ni}>\mathrm{Sb}>\mathrm{Sn}>\mathrm{Th}>\mathrm{Co}>\mathrm{Be}$;

standard deviation show the selectivity series:

$\mathrm{Pb}>\mathrm{Cu}>\mathrm{Zn}>\mathrm{V}>\mathrm{Sb}>\mathrm{Th}>\mathrm{Sn}>\mathrm{Be}>\mathrm{Cr}>\mathrm{Co}>\mathrm{Ni}$.

Urban (Zone 2): mean

$\mathrm{Pb}>\mathrm{Zn}>\mathrm{Cu}>\mathrm{V}>\mathrm{Cr}>\mathrm{Ni}>\mathrm{Sn}>\mathrm{Th}>\mathrm{Be}>\mathrm{Co}>\mathrm{Sb}$;

standard deviation, $\mathrm{Pb}>\mathrm{Cu}>\mathrm{Zn}>\mathrm{V}>\mathrm{Sn}>\mathrm{Th}>\mathrm{Co}>\mathrm{Be}>\mathrm{Cr}>$

$\mathrm{Ni}>\mathrm{Sb}$.

Rural (Zone 3): mean

$\mathrm{Zn}>\mathrm{V}>\mathrm{Cr}>\mathrm{Ni}>\mathrm{Pb}>\mathrm{Cu}>\mathrm{Sn}>\mathrm{Th}>\mathrm{Be}>\mathrm{Co}>\mathrm{Sb}$;

standard deviation, $\mathrm{Zn}>\mathrm{Cr}>\mathrm{Ni}>\mathrm{Sn}>\mathrm{Be}>\mathrm{Th}>\mathrm{Pb}>\mathrm{V}>\mathrm{Cu}>\mathrm{C}$ $\mathrm{o}>\mathrm{Sb}$.

In summary, the group of metals conforming by $\mathrm{Pb}, \mathrm{Zn}$, $\mathrm{Cr}, \mathrm{V}$ and $\mathrm{Cu}$ present the highest values for means, while the group of elements constituted of $\mathrm{Co}, \mathrm{Sn}, \mathrm{Be}$, Th and $\mathrm{Sb}$ show the lowest values. Standard deviation has a wide range of variation for the first mentioned group with an extreme value for $\mathrm{Pb}$. For the second group, however, fluctuations in values maintain within a minor range of variation. The statistical significance of correlation between $\mathrm{Co}-\mathrm{V}$; Ni-Cr; $\mathrm{Ni}-\mathrm{Co}$; $\mathrm{Sn}-\mathrm{Zn}$; $\mathrm{Co}-\mathrm{Cr}$; $\mathrm{Zn}-\mathrm{Th}$, and Sn-Th concentrations (Table 5) confirm anthropogenic sources mainly due to emissions from vehicular traffic, fossil fuel combustion, solid waste disposal and other local anthropogenic activities. Suburban and urban areas show a high correlation with Xanthoparmelia-Aspicilia species (0.9276), (0.9393) respectively. The correlation between these two areas is very good (0.9998). While in the rural area the correlation is good with Caloplaca-Aspicilia sp species (Table 4).

\section{Cluster analysis}

Cluster analysis in R-mode was performed on the lichen data set for all the examined elements. Three clusters were revealed and are shown in Figures 4 and 5. The lichen sample site shows three statistically significant clusters. Group 1 consists of the rural zone (samples 8 and 7) which is not influenced by vehicular emissions activity. Group 2 consists of suburban and 
DOI: http://dx.doi.org/10.22201/fi.25940732e.2017.18n1.010

Puy-Alquiza María Jesús, Miranda-Aviles Raúl, Zanor Gabriela Ana, Salazar-Hernández Ma. Mercedes, Ordaz-Zubia VeliaYolanda

Table 3. Concentrations $(\mu \mathrm{g} g-1)$ of the heavy metals detected in lichens collected in the three sampling sites (urban, suburban and rural) in Guanajuato city

\begin{tabular}{cccc}
\hline $\begin{array}{c}\text { URBAN } \\
(\text { IHA })\end{array}$ & $\begin{array}{c}\text { Xanthoparmelia } \\
\text { species }\end{array}$ & $\begin{array}{c}\text { Caloplaca } \\
\text { species }\end{array}$ & Aspicilia. sp \\
\hline $\mathrm{Be}$ & 4.241 & 4.1234 & 1.3245 \\
$\mathrm{Ni}$ & 4.1254 & 5.6214 & 3.6721 \\
$\mathrm{Cu}$ & 15.7321 & $\mathbf{9 1 . 2 3 4 6}$ & $\mathbf{1 7 . 9 8 7 6}$ \\
$\mathrm{Co}$ & 1.324 & 4.6389 & 1.8234 \\
$\mathrm{Sn}$ & 1.4672 & 8.3297 & 2.9314 \\
$\mathrm{Sb}$ & 0.7271 & 1.3425 & 0.8976 \\
$\mathrm{Zn}$ & $\mathbf{4 5 . 6 2 4}$ & 77.0293 & $\mathbf{7 1 . 2 3 9 4}$ \\
$\mathrm{Pb}$ & $\mathbf{9 6 . 2 1}$ & $\mathbf{9 2 . 2 3 4}$ & $\mathbf{6 0 0 . 9 2 4 3}$ \\
$\mathrm{Cr}$ & 8.9774 & 8.6234 & 5.9874 \\
$\mathrm{~V}$ & 12.9876 & $\mathbf{2 7 . 4 3 2 5}$ & 17.5289 \\
$\mathrm{Th}$ & 0.5432 & 7.3214 & 2.431 \\
\hline
\end{tabular}

\begin{tabular}{cccc}
\hline $\begin{array}{c}\text { SUBURBAN } \\
(\mathrm{IHA})\end{array}$ & $\begin{array}{c}\text { Xanthoparmelia } \\
\text { species }\end{array}$ & $\begin{array}{c}\text { Caloplaca } \\
\text { species }\end{array}$ & Aspicilia. sp \\
\hline $\mathrm{Be}$ & 0.3633 & 4.241 & 1.4687 \\
$\mathrm{Ni}$ & 4.2671 & 5.7025 & 3.4326 \\
$\mathrm{Cu}$ & 17.8363 & $\mathbf{9 0 . 5 9 6 4}$ & $\mathbf{1 8 . 2 4 2}$ \\
$\mathrm{Co}$ & 1.4692 & 4.7287 & 1.9826 \\
$\mathrm{Sn}$ & 1.5219 & 6.224 & 3.0926 \\
$\mathrm{Sb}$ & 10.7066 & 1.3558 & 0.9161 \\
$\mathrm{Zn}$ & $\mathbf{4 7 . 8 3 8}$ & $\mathbf{7 7 . 1 1 4 8}$ & $\mathbf{7 2 . 2 4 0 6}$ \\
$\mathrm{Pb}$ & $\mathbf{9 5 . 1 0 0 6}$ & $\mathbf{9 2 . 4 2 5 3}$ & $\mathbf{6 1 2 . 9 1 1 3}$ \\
$\mathrm{Cr}$ & 9.44 & 8.967 & 6.0574 \\
$\mathrm{~V}$ & 13.4938 & $\mathbf{2 7 . 6 5 9 8}$ & 17.3029 \\
$\mathrm{Th}$ & 0.5686 & 7.232 & 2.3781 \\
\hline
\end{tabular}

\begin{tabular}{cccc}
\hline $\begin{array}{c}\text { RURAL } \\
(\text { SRM })\end{array}$ & $\begin{array}{c}\text { Xanthoparmelia } \\
\text { species }\end{array}$ & $\begin{array}{c}\text { Caloplaca } \\
\text { species }\end{array}$ & Aspicilia. sp \\
\hline Be & 3.1021 & 3.1064 & $\mathbf{1 4 . 8 4 0 2}$ \\
$\mathrm{Ni}$ & $\mathbf{4 8 . 9 3 0 6}$ & 6.4322 & 14.0175 \\
$\mathrm{Cu}$ & $\mathbf{2 1 . 7 1 0 4}$ & 18.0997 & $\mathbf{1 7 . 8 9 9 7}$ \\
$\mathrm{Co}$ & $\mathbf{7 . 0 0 1 2}$ & 3.9307 & 4.641 \\
$\mathrm{Sn}$ & 5.7003 & $\mathbf{2 7 . 5 6 0 9}$ & 6.224 \\
$\mathrm{Sb}$ & 1.4497 & 1.6869 & 1.3181 \\
$\mathrm{Zn}$ & $\mathbf{9 5 . 1 0 3 5}$ & $\mathbf{1 7 2 . 9 7 1}$ & $\mathbf{5 7 . 0 9 7 7}$ \\
$\mathrm{Pb}$ & 21.4031 & $\mathbf{2 6 . 4 2 4 5}$ & 20.0676 \\
$\mathrm{Cr}$ & $\mathbf{1 0 5 . 1 5 6 5}$ & 29.3347 & 15.1433 \\
$\mathrm{~V}$ & $\mathbf{5 8 . 4 0 4 3}$ & $\mathbf{5 3 . 5 1 6 6}$ & $\mathbf{5 6 . 2 5 4 8}$ \\
$\mathrm{Th}$ & 5.1625 & $\mathbf{1 3 . 1 3 8 7}$ & 5.1917 \\
\hline
\end{tabular}




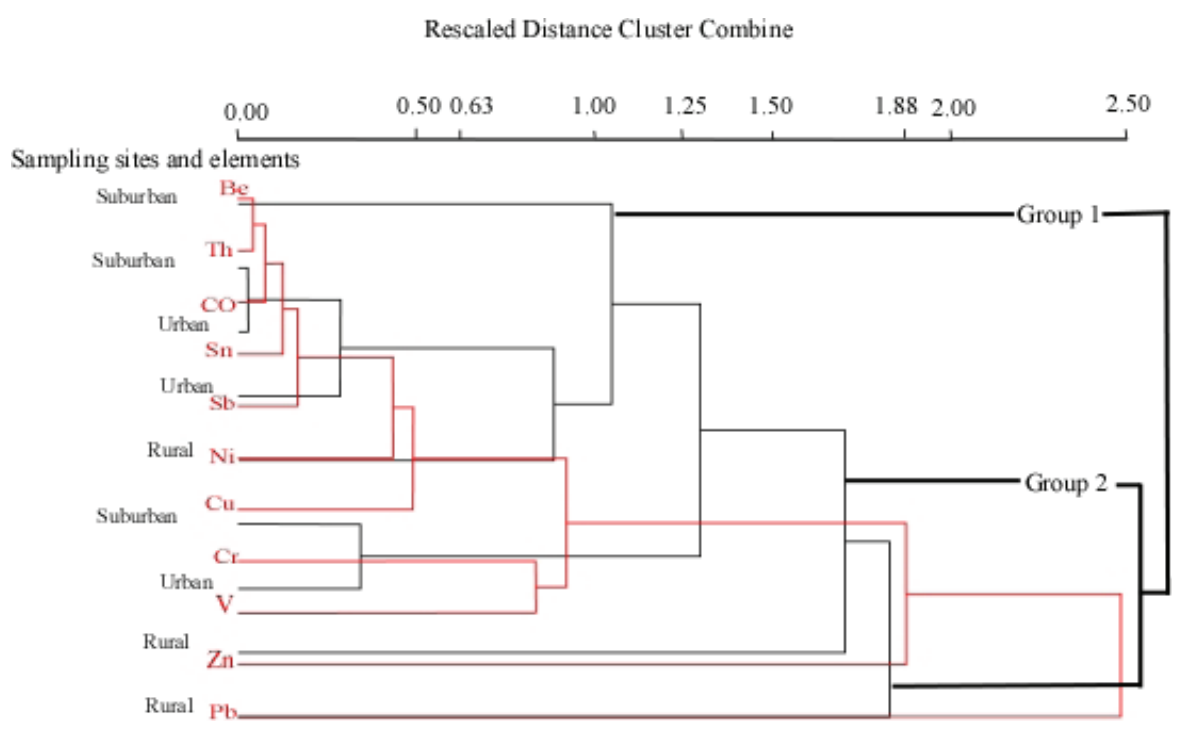

Figure 5. A dendrogram showing clustering of analyzed lichen sample sites from the study area

urban zones (samples 2 and 5), and group 3 consists of suburban, urban, and rural zones (samples 9, 4, 6, 3, 1). These results confirmed that $\mathrm{Zn}, \mathrm{Pb}$, and $\mathrm{Cu}$ derive from vehicular traffic, while $\mathrm{Co}$, and $\mathrm{V}$ have a main common source in the metallurgical industry emissions. The groups of metals in clusters 1 and 2 might indicate a geological origin, taking into account that elevated levels of these heavy metals were found in pristine area lichen samples (Xanthoparmelia and Caloplaca species). Conversely, cluster 3 suggests that both metals could derive from a common cultural source, contributing to the high pollutant contents on lichens (Caloplaca species and Aspicilia sp.). Hawksworth et al. (2005) and Conti et al. (2008) reported that fossil fuel combustion was an important anthropogenic source for $\mathrm{Pb}$ and $\mathrm{Cu}$. In the case of $\mathrm{Cu}$, important pollution sources include industrial emissions and fossil fuel combustion processes (Bernasconi et al., 2000; Cuni et al., 2004). Particularly, Guanajuato is a mining district well known all over the world for strip mining different types of metals, especially $\mathrm{Ag}$ and $\mathrm{Au}$ associated to sulphide veins. Currently, there is no record of the emissions released to the environment by the mineral industry, but it is known that the particular amount of $\mathrm{Pb}$ per year is $6.4 \mu \mathrm{g} \mathrm{g}^{-1}$. This activity, combined with an increase in human population and the related heavy vehicular traffic could act as the primary sources of $\mathrm{Pb}$ and $\mathrm{Cu}$ emissions. Although $\mathrm{Zn}$ is a metal commonly considered to be emitted from anthropogenic sources (traffic, metallurgy, waste incineration), this study shows much higher concentrations in pristine zones. However, Aspicilia sp. accumulates this metal in higher contents in subur- ban and urban zones and it is possible that part of the released $\mathrm{Zn}$ in this area may be derived from mining and vehicular emissions.

\section{Estimating Pollution impacts}

\section{THE LEVELS OF HEAVY METALS IN LICHENS}

In general, high levels of the heavy metals were observed in all studied lichen samples (Tables 2 and 3). These lichens have the ability to accumulate $\mathrm{Pb}, \mathrm{Cu}, \mathrm{Co}, \mathrm{Zn}$, and V. The Xanthoparmelia species has the ability to accumulate $\mathrm{Pb}, \mathrm{Zn}$, and $\mathrm{Cu}$, whilst Caloplaca species and Aspicilia sp., have accumulated $\mathrm{Pb}, \mathrm{Cu}, \mathrm{Co}, \mathrm{Zn}$, and $\mathrm{V}$, respectively. It is well known that the deposition of $\mathrm{Pb}$ is mainly incorporated from street dust, by vehicular emissions and fuel combustion from circulating trucks and cars (Hawksworth et al., 2005; Conti et al., 2008). The $\mathrm{Zn}$ and $\mathrm{Cu}$ in Caloplaca species indicate that lichen concentrated these elements. $\mathrm{Zn}$ and $\mathrm{Cu}$ concentrations are due to industrial emissions of steel or regular wear of engines of automobiles, abrasion and burning of tires (Bernasconi et al., 2000). The Co and V concentrations in the Aspicilia sp. lichen show that the above element comes from metallurgical industry emissions (Bernasconi et al. 2000). According to Bennett \& Wetmore (1999), the corticolous species would accumulate a higher concentration of atmospheric elements because they are more exposed to a mixed atmosphere than the saxicolous species. However, higher concentrations of heavy metals were found in saxicolous species (Xanthoparmelia, Caloplaca and Aspicilia sp). 
DOI: http://dx.doi.org/10.22201/fi.25940732e.2017.18n1.010

Puy-Alquiza María Jesús, Miranda-Aviles Raúl, Zanor Gabriela Ana, Salazar-Hernández Ma. Mercedes, Ordaz-Zubia VeliaYolanda

Table 4. Statistical summary of Heavy Metals concentrations $\left(\mu \mathrm{g} \mathrm{g}^{-1}\right)$ in lichens collected at 7 sampling sites. SD, standard deviation; Min, minimum; Max, maximum; Med, median; N, number of samples over detection limits. Mean, standard deviations, minimums, maximums and medians were calculated using zero for under detection limit values

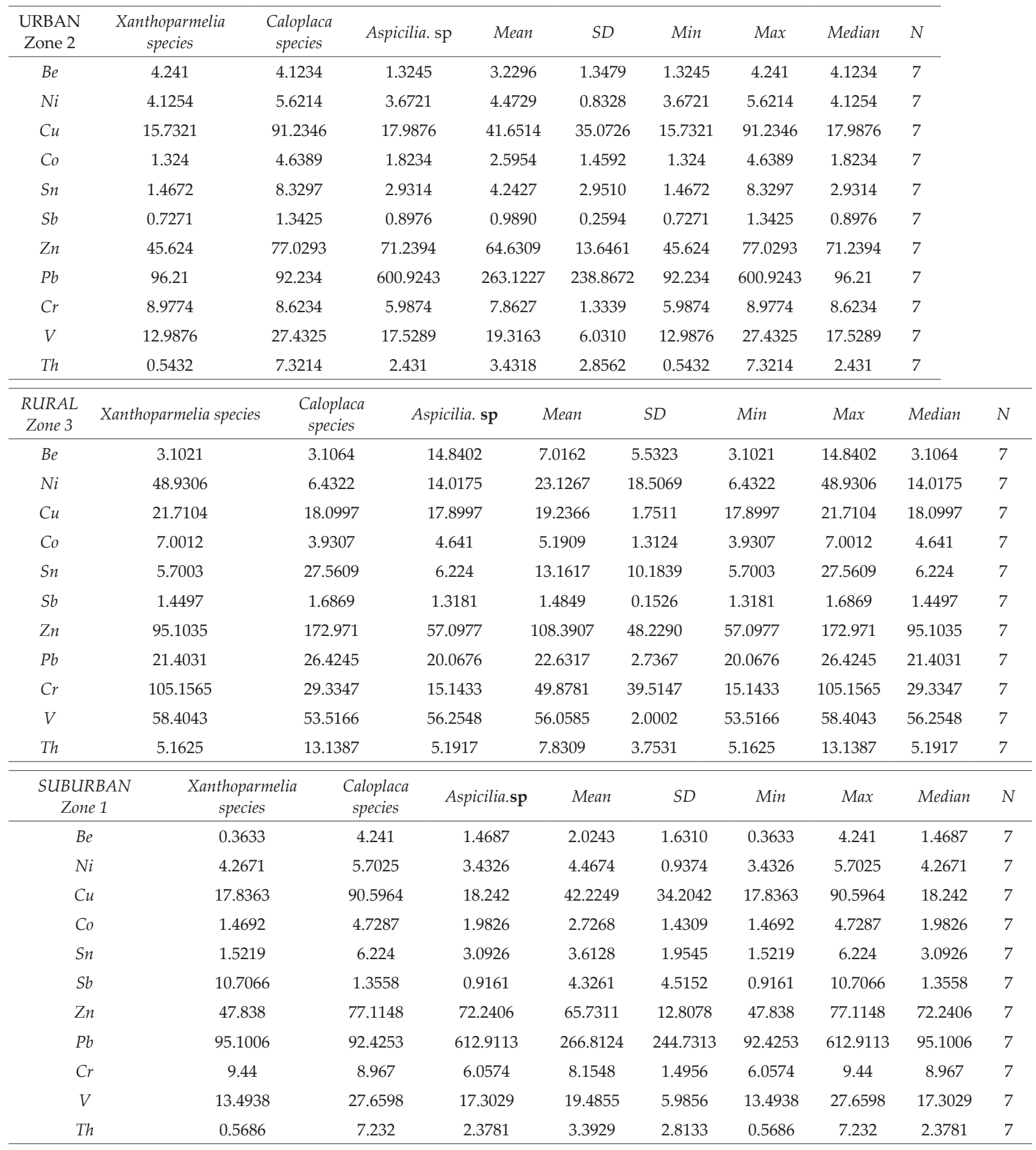


DOI: http://dx.doi.org/10.22201/fi.25940732e.2017.18n1.010

Study of the Distribution of Heavy Metals in the Atmosphere of the Guanajuato City: Use of Saxicolous lichen Species as Bioindicators

Table 5. Values of correlation coefficient $(\mathrm{P}<0.01)$ between sampling sites (suburban, urban and Rural) and the amounts of heavy metals found in saxicolous lichen

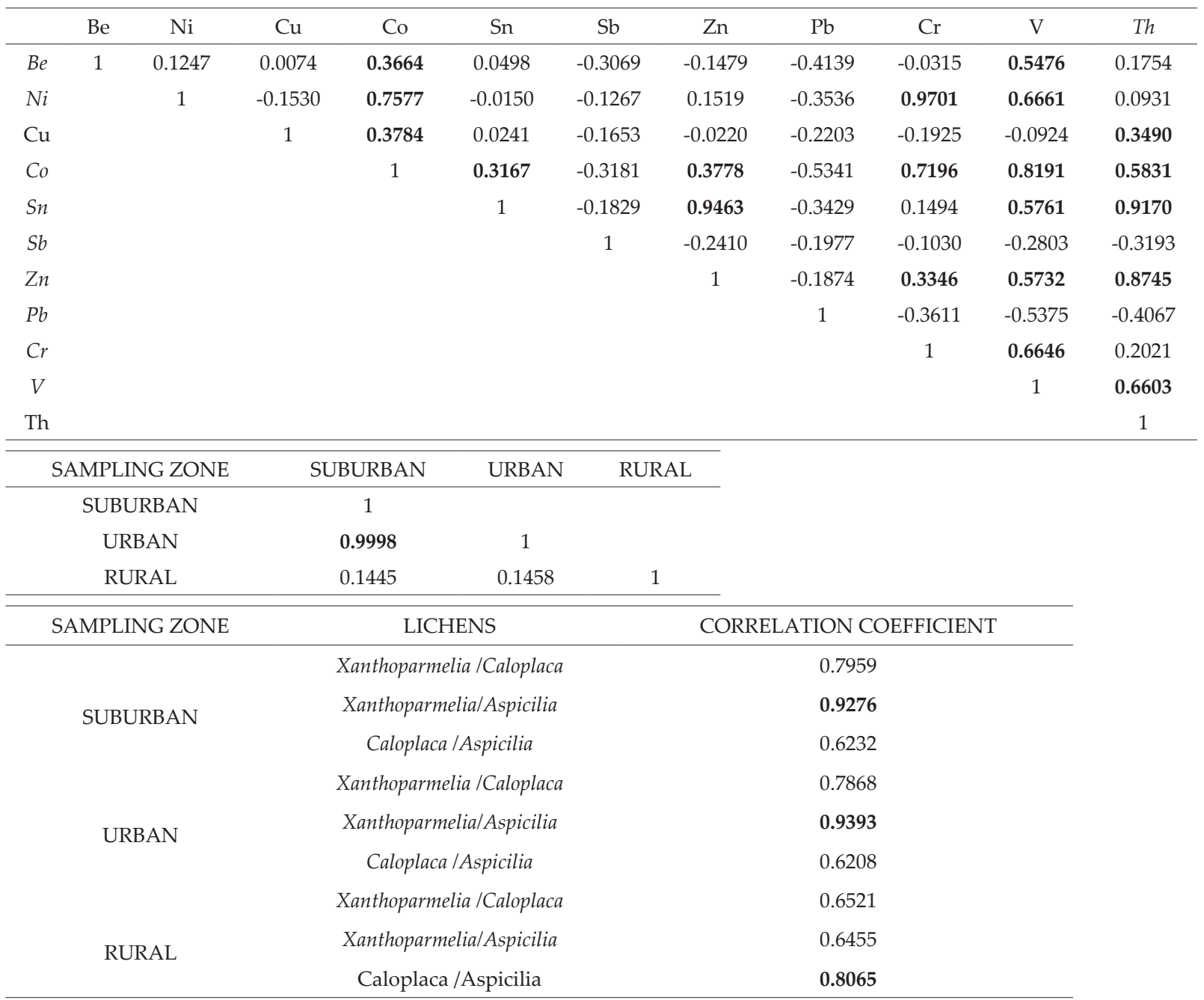

\section{CFs}

The contamination Factor is defined by Tomlinson et al. (1980) as the metal concentration in sediment divided by some background base value for each element. The background value corresponds in these work to data obtained from the rural (pristine forest "La Bufa"), (Table 2). The ranges used to describe the contamination factor are: $\mathrm{CF}<1$ is considered as low contaminated; $1<\mathrm{CF}<3$ is moderate contamination; $3<\mathrm{CF}<6$ is considerable contamination and $\mathrm{CF}>6$ is high contaminations. The CF values for the various metals are shown in table 6. The metal CF levels at all sample in urban site is present in the following order Xanthoparmelia species: $\mathrm{Pb}>$ $\mathrm{Be}>\mathrm{Cu}>\mathrm{Sb}>\mathrm{Zn}>\mathrm{Sn}>\mathrm{V}>\mathrm{Co}>\mathrm{Th}>\mathrm{Cr}>\mathrm{Ni}$; Caloplaca species: $\mathrm{Cu}>\mathrm{Zn}>\mathrm{Cu}>\mathrm{Sb}>\mathrm{Sn}>\mathrm{Th}>\mathrm{Cr}>\mathrm{Co}>\mathrm{V}>\mathrm{Ni}>\mathrm{Be}$; Aspicilia sp: $\mathrm{Pb}>\mathrm{Zn}>\mathrm{Cu}>\mathrm{Sb}>\mathrm{Sn}>\mathrm{Th}>\mathrm{Cr}>\mathrm{Co}>\mathrm{V}>\mathrm{Ni}>\mathrm{Be}$.
In suburban site the following order is Xanthoparmelia species: $\mathrm{Sb}>\mathrm{Pb}>\mathrm{Cu}>\mathrm{Zn}>\mathrm{Sn}>\mathrm{Co}>\mathrm{V}>\mathrm{Be}>\mathrm{Th}>\mathrm{Cr}>\mathrm{Ni}$; Caloplaca species: $\mathrm{Cu}>\mathrm{Pb}>\mathrm{Th}>\mathrm{Be}>\mathrm{Co}>\mathrm{Ni}>\mathrm{Sb}>\mathrm{V}>\mathrm{Zn}>\mathrm{Cr}>$ Sn; Aspicilia sp: $\mathrm{Pb}>\mathrm{Zn}>\mathrm{Cu}>\mathrm{Sb}>\mathrm{Sn}>\mathrm{Th}>\mathrm{Co}>\mathrm{Cr}>\mathrm{V}>\mathrm{Ni}>$ Be.

Lead concentrations are very high in the study area, the CF ranged between 3.49-30.54 suggesting high contamination in all sites (urban and suburban). Copper concentration is relatively high in the study area, the CF ranged between 0.72-5.04 suggesting moderate contamination. Antimony concentration is present high in suburban area, the CF is 7.38 suggesting high concentration. Low concentration factor was observed for Be, $\mathrm{Ni}, \mathrm{Co}, \mathrm{Sn}, \mathrm{Zn}, \mathrm{Cr}, \mathrm{V}$, Th at all sites. 
DOI: http://dx.doi.org/10.22201/fi.25940732e.2017.18n1.010

Puy-Alquiza María Jesús, Miranda-Aviles Raúl, Zanor Gabriela Ana, Salazar-Hernández Ma. Mercedes, Ordaz-Zubia VeliaYolanda

PLI

We calculated the Pollution loading Index (PLI) using the following equation

$\mathrm{PLI}=\left(\mathrm{CF}_{1} \times \mathrm{CF}_{2} \times \mathrm{CF}_{3} \times \mathrm{CF}_{4} \times \mathrm{CF}_{5} \times \ldots \ldots \mathrm{CF}_{\mathrm{n}}\right)^{1 / \mathrm{n}}$

where

PLI= pollution loading index

$\mathrm{CF}=$ contamination factor

$\mathrm{n}=$ number of metals investigated
The PLI was calculated for the two areas under investigation using the eleven investigated metals (Be, $\mathrm{Ni}, \mathrm{Cu}, \mathrm{Co}, \mathrm{Sn}, \mathrm{Sb}, \mathrm{Zn}, \mathrm{Pb}, \mathrm{Cr}, \mathrm{V}$ and Th). It was observed that the highest PLI was found at Suburban area (0.037), while the lowest was calculated for Urban (0.024), the calculated PLI were found in the following sequences: Suburban $>$ Urban (Table 6).

Table 6. Lichens and their pollution index factors (PIF): contamination factors (CFs) and pollution load indices (PLI)

\begin{tabular}{|c|c|c|c|c|c|c|c|c|c|c|c|}
\hline $\begin{array}{l}\text { URBAN } \\
\text { (IHA) }\end{array}$ & $\begin{array}{c}\text { Xanthoparmelia } \\
\text { species }\end{array}$ & $\mathrm{CFs}$ & PLI & \multicolumn{2}{|c|}{$\begin{array}{c}\text { Caloplaca } \\
\text { species }\end{array}$} & CFs & PLI & $\begin{array}{c}\text { Aspicilia } \\
\text { sp }\end{array}$ & CFs & PLI & \\
\hline$B e$ & 4.241 & 1.3671 & 0.0000 & \multicolumn{2}{|c|}{4.1234} & 1.3273 & 0.0196 & 1.3245 & 0.0892 & 0.0053 & \\
\hline $\mathrm{Ni}$ & 4.1254 & 0.0843 & & \multicolumn{2}{|c|}{5.6214} & 0.8739 & & 3.6721 & 0.2619 & & \\
\hline $\mathrm{Cu}$ & 15.7321 & 0.7246 & & \multicolumn{2}{|c|}{91.2346} & 5.0406 & & 17.9876 & 1.0049 & & \\
\hline Co & 1.324 & 0.1891 & & \multicolumn{2}{|c|}{4.6389} & 1.180 & & 1.8234 & 0.3928 & & \\
\hline Sn & 1.4672 & 0.2573 & & \multicolumn{2}{|c|}{8.3297} & 0.3022 & & 2.9314 & 0.4709 & & \\
\hline$S b$ & 0.7271 & 0.5015 & & \multicolumn{2}{|c|}{1.3425} & 0.7958 & & 0.8976 & 0.6809 & & \\
\hline $\mathrm{Zn}$ & 45.624 & 0.4797 & & \multicolumn{2}{|c|}{77.0293} & 0.4453 & & 71.2394 & 1.2476 & & \\
\hline $\mathrm{Pb}$ & 96.21 & 4.4957 & & \multicolumn{2}{|c|}{92.234} & 3.4904 & & 600.9243 & $\begin{array}{ll}3 & 29.945\end{array}$ & & \\
\hline $\mathrm{Cr}$ & 8.9774 & 0.0853 & & \multicolumn{2}{|c|}{8.6234} & 0.2939 & & 5.9874 & 0.3953 & & \\
\hline$V$ & 12.9876 & 0.2223 & & & 325 & 0.5125 & & 17.5289 & 0.3115 & & \\
\hline Th & 0.5432 & 0.1052 & & & & 0.5572 & & 2.431 & 0.4682 & & \\
\hline $\begin{array}{l}\text { SUBURBAN } \\
\text { (IHA) }\end{array}$ & $\begin{array}{l}\text { Xanthoparmeli } \\
\text { species }\end{array}$ & & CFs & PLI & $\begin{array}{r}\text { Calo } \\
\text { spe }\end{array}$ & $\begin{array}{l}\text { laca } \\
\text { cies }\end{array}$ & CFs & PLI & $\begin{array}{l}\text { Aspicilia } \\
\text { sp }\end{array}$ & $\mathrm{CFs}$ & PLI \\
\hline $\mathrm{Be}$ & 0.3633 & & 0.1171 & 0.0000 & 4.2 & & 1.3652 & 0.037 & 1.4687 & 0.0989 & 0.0005 \\
\hline $\mathrm{Ni}$ & 4.2671 & & 0.0872 & & 5.7 & 25 & 0.8865 & & 3.4326 & 0.2448 & \\
\hline $\mathrm{Cu}$ & 17.8363 & & 0.8215 & & 90.5 & 964 & 5.0054 & & 18.242 & 1.0191 & \\
\hline Co & 1.4692 & & 0.2098 & & 4.7 & 287 & 1.2030 & & 1.9826 & 0.4271 & \\
\hline Sn & 1.5219 & & 0.2669 & & 6.2 & & 0.2258 & & 3.0926 & 0.4968 & \\
\hline$S b$ & 10.7066 & & 7.385 & & 1.3 & & 0.8037 & & 0.9161 & 0.6950 & \\
\hline $\mathrm{Zn}$ & 47.838 & & 0.5030 & & 77.1 & 148 & 0.4458 & & 72.2406 & 1.2652 & \\
\hline $\mathrm{Pb}$ & 95.1006 & & 4.4433 & & 92. & 253 & 3.4977 & & 612.9113 & 30.5423 & \\
\hline $\mathrm{Cr}$ & 9.44 & & 0.0897 & & & & 0.3056 & & 6.0574 & 0.4000 & \\
\hline$V$ & 13.4938 & & 0.2310 & & 27. & 598 & 0.5168 & & 17.3029 & 0.3075 & \\
\hline Th & 0.5686 & & 0.1101 & & 7.2 & 32 & 1.3929 & & 2.3781 & 0.4580 & \\
\hline
\end{tabular}




\section{Conclusions}

Our results represent the first study of heavy metals in saxicolous lichens from the Guanajuato city. The elemental concentrations of heavy metals in saxicolous lichens (Xanthoparmelia mexicana (Gyeln.) Hale, Xanthoparmelia tasmanica (Hook. f. \& Taylor) Hale, Caloplaca aff. brouardii (B.deLesd.)Zahlbr, Caloplaca aff. ludificans Arup, and Aspicilia sp.) were obtained from the distribution of heavy metals in the suburban, urban, and rural zones of the Guanajuato city and identify places with higher levels of heavy metal concentration. The concentration of these metals was observed to be in higher range as maximum values of $\mathrm{Pb}, \mathrm{Zn}, \mathrm{Cu}$ and $\mathrm{V}$, were reported from the lichen samples from the suburban and urban zone in the Guanajuato city. However, the accumulations of $\mathrm{Ni}, \mathrm{Co}$, and $\mathrm{Th}$ from both zones are more or less similar in concentration. Metals such as, $\mathrm{Zn}, \mathrm{Cr}, \mathrm{V}$ exhibits the highest concentrations in rural lichen samples, whereas $\mathrm{Cu}$ and $\mathrm{Pb}$ show the maximum contents in suburban and urban lichen samples. These results suggest that a natural source (rock) could be the main controlling source of concentrations in the studied lichens within the pristine area. Elevated $\mathrm{Pb}, \mathrm{Cu}$, $\mathrm{Zn}$ and $\mathrm{V}$ levels measured in the urban and suburban sampling sites point out sources of anthropogenic origin. In Guanajuato city, fossil fuel combustion due to heavy traffic and mining activities are suggested to be important anthropogenic emission sources for $\mathrm{Pb}$ and $\mathrm{Cu}$. A selective bioaccumulation potential could be recognized among the studied lichen communities for certain elements. Xanthoparmelia species show in urban and suburban area the highest accumulation capacity for $\mathrm{Zn}$ and $\mathrm{Pb}$, whilst Caloplaca species best accumulate $\mathrm{Zn}, \mathrm{Pb}, \mathrm{V}$ and $\mathrm{Cu}$. Aspicilia sp. has the highest $\mathrm{Pb}, \mathrm{Cu}$ and $\mathrm{Zn}$ accumulation ability, with extreme values reaching $612.91 \mu \mathrm{g} \mathrm{g}^{-1}$. These results indicate that Xanthoparmelia species could be a useful species for biomonitoring elevated levels of $\mathrm{Zn}$ and $\mathrm{Pb}$ and Caloplaca for $\mathrm{Zn}, \mathrm{Pb}, \mathrm{V}$ and $\mathrm{Cu}$. Aspicilia sp. tolerates large and toxic amounts of $\mathrm{Pb}$, making us consider this particular species as a good bioindicators of $\mathrm{Pb}$ air pollution. Correlation analyses showed a high affinity among $\mathrm{Co}-\mathrm{V}$; $\mathrm{Ni}-\mathrm{Cr}$; Ni-Co; Sn$\mathrm{Zn} ; \mathrm{Co}-\mathrm{Cr} ; \mathrm{Zn}-\mathrm{Th}$; and Sn-Th. The results of the first cluster suggest that geology mainly contributes with metal contents in lichen samples. The second cluster also indicates a natural source controlling metal concentrations in lichens with the exception of $\mathrm{Zn}$, which could be partly supplied by vehicular emissions. The associations of $\mathrm{Pb}$ and $\mathrm{Cu}$ indicate that emissions from heavy traffic, industrial and mining activities control the metal levels in lichen samples.
Pollution evaluation using the PLI index indicates Caloplaca and Aspicilia have higher $\mathrm{CFs}$ in $\mathrm{Be}, \mathrm{Cu}, \mathrm{Co}$, $\mathrm{Pb}, \mathrm{Zn}$ and $\mathrm{Th}$, when compared with Xanthoparmelia $(\mathrm{Be}, \mathrm{Pb}$ and $\mathrm{Sb}$ ). These results show a higher bioaccumulation potential for the Caloplaca and Aspicilia species and a lower bioaccumulation capacity for the Xanthoparmelia species. The studied species in this work are proposed for biomonitoring in the Guanajuato city, specifically in respect to $\mathrm{Pb}, \mathrm{Sb}$ and $\mathrm{Cu}$, and to a minor degree, $\mathrm{Co}, \mathrm{Be}, \mathrm{Th}$ and $\mathrm{Zn}$. The results of this study could be used as a baseline for know the effects of the pollution at the Miners sites.

\section{ACKNOWLEDGMENTS}

The research was conducted with the financial support of DAIP-University of Guanajuato, project 00073/11. Special thanks to M. in C. Ofelia Perez Arvizu for the preparation and measurement of samples analyzed in the laboratory ultraclean ICP-MS, UNAM, Juriquilla.

\section{RefERENCES}

Addison P.A. and Puckett K.J. Deposition of atmospheric pollutants as measured by lichen element content in the Athabasca oil sands area. Canadian Journal Botany, volume 58, 1980: 23232334.

Bernasconi E., De Venito I.E., Martínez L.D., Raba J.Liquen Usnea densirostra como bioindicador de metales pesados. Determinación por ICP-AES acoplado con nebulizador ultrasónico. Ars Pharmaceutica, volume 41, 2000: 249-257.

Bennett J.P. and Wetmore C.M. Changes in element contents of selected lichens over 11 years in Northern Minnesota, USA. Environmental and Experimental Botany, volume 41, 1999: 75-82.

Boonpragob K., Nash T.H., Fox C.A. Seasonal deposition patterns of acidic ions and ammonium to the lichen Ramalina menziesii Tayl. In Southern California. Environmental and experimental Botany, volume 29, 1989: 187-197.

Bhuiyan M.A.R. and Hoque M.Z. Free radical scavenging activities of Zizyphus mauritiana. Electronic Journal Environmental Agricola Food Chemistry, volume 9 (issue 1), 2010: 199-206.

Brunialti G. and Frati L. Biomonitoring of nine elements by the lichen Xanthoria parietina in Adriatic Italy: a retrospective study over a 7-year time span. Science Total Environment, volume 387, 2007: 289-30.

Conesa H.M., García G., Faz A., Arnaldos R. Dynamics of metal tolerant plant communities development in Mine Tailings from the Cartagena-La Union Mining District (SE Spain) and their interest for further revegetation purposes. Chemosphere, volume 68, 2007: 1180-1185.

Conti M.E., Pino A., Botré F., Boca B., Alimonti A. Lichen Usnea barbata as a biomonitor of airbone elements deposition in the 
Province of Tierra del Fuego (southern Patagonia, Argentina). Ecoxitology and Environmental Safety, volume 72, 2008: 10821089.

Farner A.M., Bates J.W., Bell J.N.B. Ecophysiological effects of acid rain on brypphytes and lichens. In: Bryophytes and lichens in a changing environment. Bates J.W. and A.M. Farmer eds. Clarendon Press, Oxford, 1992, pp. 284-313.

Gartner Lee Limited CE, Jones and Associates, Gamberg Consulting, Geological Survey of Canada, and RWDI Air Inc. Anvil Range Mine Complex- Terrestrial effects study: Investigation into metal concentrations in vegetation, wildlife and soils. Draft for Discussion, prepared for Deloitte and Touche Inc. on behalf of the Faro Mine Closure Planning Office, 2006.

Garty J. Lichens as biomonitors for heavy metal pollution. In: Markert, B. (Ed.), Plants as Biomonitors: Indicators for Heavy Metals in the Terrestrial Environment, VCH, Weinheim, 1993, pp. 193-263.

Garty J. Biomonitoring atmospheric heavy metals with lichens: theory and application. Critical Reviews in Plant Sciences, volume 20 (issue 4), 2001: 309-371.

Gries C. Lichens as indicators of air pollution. In: Nash III, T.H. (Ed.), Lichen Biology. Cambridge University Press, Cambridge, 1996, pp. 240-254.

Harikumar P.S., and Jisha T.S. Distribution pattern of trace metal pollutants in the sediments of an urban wetlands in the southwest coast of India. International Journal of Engineering, volume 2 (issue 5), 2010: 840-850.

Harikumar P.S., Nasir U.P., Mujeebu Rahma M.P. Distribution of heavy metals in the core sediments of a tropical wetland system. International Journal. Environmental Science Technology, volumen 6 (issue 2), 2009: 225-232.

Hawksworth D., Iturriaga T., Crespo A. Liquenes como bioindicadores inmediatos de contaminación y cambios medio-ambientales en los trópicos. Revista Iberoamericana Micología, volume 22, 2005: 71-82.

Jeran Z., Jac' imovic R., Batic F., Mavsar R. Lichens as integrating air pollution monitors. Environmental Pollution, volume 120, 2002: 107-113.
Kinalioglu K., Ozbucak T.B., Kutbay H.G., Huseyinova R., Bilgin A., Demirayak A. Biomonitoring of trace elements with lichens in Samsun City, Turkey. Ekoloji, volume 19, 2010:50-53.

Leygonie R. Heavy metals in the atmosphere: sources, emissions, measurement, effects. Pollution Atmospherique, volume 35, 1993: 63-74.

Mori L., Gomez-Tuena A., Schaaf P., Goldstein S.L.,Perez-Arvizu O., Solis-Pichardo G. Lithospheric removal as a trigger for flood basalt magmatism in the Trans-Mexican Volcanic Belt. Journal of Petrology, volume 50 (issue 11), 2009: 2157-2186.

Nash T.H. III and Gries C. Lichens as bio-indicators of sulfur dioxide. Symbiosis, volume 33, 2002: 1-21.

Nash T.H. III, Ryan B., Diederich P., Gries C., Bungarts F. Lichen flora of the greater sonoran desert region, vol. II, Lichens Unlimited, Arizona State University, USA, 2004, pp.742.

Nash T.H. III, Ryan B.D., Diederich P., Gries C., Bungarts F. Lichen flora of the greater sonoran desert region, vol. III, Lichens Unlimited, Arizona State University, USA, 2007, pp. 567.

Nieboer E., Richardson D.H.S., Tomassini F.D. Mineral uptake and release by lichens: an overview. The Bryologist volume 81 (issue 2), 1978: 226-246.

Nimis P.L., Scheidegger C., Wolseley P.A. Monitoring with lichens-monitoring lichens. NATO Science Series IV, Earth and Environmental Sciences, vol. 7, Kluwer Academic Publishers, 2002, pp. 408.

Nyarko B.J.B., Serfor-Armah Y., Akaho E.H.K., Adomako D., Osae S. Determination of heavy metal pollution levels in lichens at Obuasi gold mining area in Ghana. Journal Application Science Technology, volume 9 (issues 1, 2), 2004: 28-33.

Puy-Alquiza M.J., Miranda-Avilés R., Salazar-Hernández C., Vega-González M., Cervantes J. Characterization petrophysical of the losero formation in the historical architecture of the Guanajuato city, Mexico. Revista Ingeniería Investigación y tecnología, volume XIV (issue 2), 2013: 191-202.

Tomlinson D.L., Wilson J.G., Harris C.R., Jeffrey D.W. Problems in the assessments of heavy-metal levels in estuaries and formation of a pollution index. Helgol Meeresunters, volume 33, 1980: 566-575. 


\section{Citation for this article:}

\section{Chicago style citation}

Puy-Alquiza, María Jesús, Raúl Miranda-Avilés, Gabriela Ana Zanor, María Mercedes Salazar-Hernández, Velia Yolanda Ordaz-Zubia. Study of the Distribution of Heavy Metals in the Atmosphere of the Guanajuato City: Use of Saxicolous Lichen Species as Bioindicators, Ingeniería Investigación y Tecnología, XVIII, 01 (2017): 111-126.

\section{ISO 690 citation style}

Puy-Alquiza M.J., Miranda-Aviles R., Zanor G.A., Salazar-Hernández M.M., Ordaz-Zubia V.Y., Study of the Distribution of Heavy Metals in the Atmosphere of the Guanajuato City: Use of Saxicolous Lichen Species as Bioindicators, Ingeniería Investigación y Tecnología, volume XVIII (issue 1), January-March 2017: 111-126

\section{About the AUthORS}

María Jesús Puy y Alquiza. Geologist by profession, Ph.D. in Geology at the CICIMAR. Full professor of the University of Guanajuato. Concentrate in the investigation of sedimentology and stratigraphy.

Raúl Miranda-Aviles. Received his Ph.D in 2002 from Bordeaux University, France. From 1993 to 2000, he was an exploration geologist in Mexico and Central America. Currently he is a Full professor in the Department of Mines and Geology of University of Guanajuato. His research interest include Environmental Sedimentology, Mineralogy, Structural Geology and Petrology.

Gabriela Ana Zanor. Associate professor in the Department of Environmental Sciences, Universidad de Guanajuato, Mexico. Ph.D. in Geology at the University of Cordoba (Argentina). My research interests include Environmental Geology and Paleolimno$\log$.

Ma. Mercedes Salazar-Hernández. Ph D. in Chemistry at the Guanajuato University. Associate professor in the University of Guanajuato. Concentrate in the investigation of materials.

Velia Yolanda Ordaz-Zubia. PhD in Architecture with specialty in urban studies. Full time professor in University of Guanajuato. Desirable profile in PRODEP. Research interest: urban and regional items, heritage, hystorical sites and cities, sustainability, local development. 